\title{
The use of social media among Indonesia's Migrant Workers (IMWs)
}

\section{Penggunaan media sosial dikalangan Pekerja Migran Indonesia (PMI)}

\author{
Citra Hennida ${ }^{1 *}$, Kandi Aryani², \& Sri Endah Kinasih ${ }^{3}$ \\ ${ }^{1}$ Department of International Relations, Faculty of Social and Political Sciences, Universitas Airlangga \\ ${ }^{2}$ Department of Digital Humanities, Faculty of Art and Humanities, King's College London \\ ${ }^{3}$ Department of Anthropology, Faculty of Social and Political Sciences Universitas Airlangga \\ Address: ${ }^{1,3}$ Jalan Dharmawangsa Dalam, Airlangga, Surabaya, East Java, Indonesia 60286 \\ ${ }^{2}$ Strand, London WC2R 2LS, United Kingdom \\ Email: citra.hennida@fisip.unair.ac.id*,kandi_aryani.1.suwito@kcl.ac.uk, \\ \& sriendah.kinasih@fisip.unair.ac.id
}

Article History: Received 9 September 2020; Accepted 13 January 2020; Published Online 19 January 2021

\begin{abstract}
Netizens often use social media as a medium for activism, including Indonesia's Migrant Workers (IMWs). Social media with networked characteristics has succeeded in lifting narratives in particular groups that have not been heard a lot and have escaped mainstream media scrutiny. Starting from the development of communication between IMWs, we raise the extent to which IMWs use social media as a medium for social activism, especially for IMWs protection issues and social media's main content uploaded IMWs. This study aims to analyze to what extent social media is used by IMWs for social activism related to issues concerning the protection of migrant workers and what influences their behavior when using social media. We use a social media activism framework within the social media platform. Researchers collected data from MarchSeptember 2019 through participant observation, in-depth interviews, and focused discussions that presented 15 representatives from assistants, NGOs, and academics in Malang. There were also 25 IMWs representatives with placement experience in Hong Kong, Taiwan, Malaysia, and Saudi Arabia. We found that the majority of IMWs use social media as a means of communicating between themselves and their families in the country; however, social media content for social activism is low, especially for the issue of IMWs protection. The culture and legal system in the countries of origin and destination countries influence the low level of participation in the content they create. IMWs is placed in a country with a more open culture, where local laws are more apparent in the protection of IMWs, so IMW's social media content is more open and willing to provide testimony on the problems that exist around them and vice versa. Therefore, although social media is massive among IMWs, it is not linear with content production that leads to protection.
\end{abstract}

Keywords: social media; activism; Indonesia’s Migrant Workers

\begin{abstract}
Abstrak
Netizen kerap menggunakan media sosial sebagai media untuk berkegiatan, termasuk Pekerja Migran Indonesia (PMI). Media sosial yang bercirikan berjejaring berhasil mengangkat narasi kelompok tertentu yang belum banyak terdengar dan luput dari sorotan media arus utama. Berawal dari pengembangan komunikasi antar PMI, kami mengangkat sejauh mana PMI menggunakan media sosial sebagai media aktivisme sosial, terutama untuk isu perlindungan PMI dan konten utama media sosial PMI yang diunggah. Penelitian ini bertujuan untuk menganalisis sejauh mana media sosial digunakan PMI untuk aktivisme sosial terkait isu-isu perlindungan PMI dan apa saja yang mempengaruhi perilakunya saat menggunakan media sosial. Kami menggunakan kerangka aktivisme media sosial dalam platform media sosial. Peneliti mengumpulkan data pada Maret-Oktober 2019 melalui observasi partisipan, wawancara mendalam, dan diskusi terfokus yang menghadirkan 15 perwakilan dari pendamping, LSM, dan akademisi di Malang. Terdapat pula 25 perwakilan PMI dengan pengalaman penempatan di Hong Kong, Taiwan, Malaysia, dan Arab Saudi. Kami menemukan bahwa mayoritas PMI menggunakan media sosial sebagai sarana komunikasi antara dirinya dan keluarganya di Tanah Air; namun, konten media sosial untuk aktivisme sosial masih rendah, terutama untuk isu perlindungan PMI. Budaya dan sistem hukum di negara asal dan negara tujuan mempengaruhi rendahnya tingkat partisipasi dalam konten yang mereka buat. PMI yang ditempatkan di negara dengan budaya yang lebih terbuka, di mana peraturan daerah lebih terlihat dalam perlindungan PMI, sehingga konten media sosial PMI lebih terbuka dan bersedia memberikan testimoni atas permasalahan yang ada di sekitarnya dan sebaliknya. Oleh karena itu, meski masif di kalangan PMI, media sosial tidak linier dengan produksi konten yang mengarah pada perlindungan.
\end{abstract}

Kata kunci: media aktivisme sosial; media sosial; Pekerja Migran Indonesia 


\section{Introduction}

Working abroad is still favorable among the workforce in Indonesia because of the imbalance of job vacancies and the number of workers in the country. The National Agency for the Placement and Protection of Indonesian Workers (hereafter called BN2PTKI) shows that the total Indonesian workforce in 2014 was 176 million people; however, $68 \%$ only graduated with low-quality education in elementary school and junior high school. The low level of education of the Indonesian workforce causes many of them to target informal jobs abroad. BN2PTKI noted that the number of Indonesian Migrant Workers (IMWs) for the 2014-2019 period was 1.55 million. Ten favorite destination countries are Taiwan, Malaysia, Hong Kong, Singapore, South Korea, Saudi Arabia, Brunei Darussalam, Japan, Turkey, and Kuwait. Meanwhile, the dominance of IMWs nationally is still female, as many as 198.975 people (70\%), while IMWs for men is 84.665 (30\%) (Badan Nasional Penempatan dan Perlindungan Tenaga Kerja Indonesia 2019).

The level of interest in working abroad is linear, with the increasing number of human trafficking. Data show that: 1) in 2013, there were 160 cases, 2) in 2014 there were 173 cases, 3) in 2015, there were 184 cases, and 4) in 2016, there were 263 cases. BNP2TKI identifies problems from Implementing the Placement of Indonesian Private Workers or Pelaksana Penempatan Tenaga Kerja Indonesia Swasta (PPTKIS) level, BNP2TKI, policies, and regulations IMWs conditions. Problems include the complicated process of placing IMWs, which has to bear expensive shipping costs, the quality of service to IMWs is still low at home and abroad, responsive protection services, and the not anticipatory and unclear direction of government policies. As a result, there are many cases of illegal levies and intimidation to IMWs, IMWs do not meet the requirements to continue to depart, the number of illegal IMWs is still large, and the presence of IMWs abroad is not detected (Badan Nasional Penempatan dan Perlindungan Tenaga Kerja Indonesia 2016). These problems arise due to a lack of IMWs' capacity, lack of information understanding, and limited access to information sources. Even if it is available, IMWs' ability to digest information is low due to low educational background.

Sources of IMWs information go in one direction, many Indonesian Employment Services Companies (hereafter called PJTKI) provide. PJTKIs has not yet carried out disseminating information comprehensively about the potential emergence of human trafficking. Even in many cases, PJTKIs are traffickers, and this information is easy to obtain for almost everyone, including IMW. Unfortunately, accessing information via this smartphone has drawbacks too. First, the amount of information varies with many sources, and a large amount of information obscures the message. Second, the information interacts only in one direction, and the internet speeds up a communication; however, it can cause misinterpretation of the messenger to the message recipient. The messenger already feels that he makes a difference by delivering a one-way message; the recipient may have participated by conveying his agreement by liking it (Harlow \& Guo 2014).

Along with the arrival of smartphones and the internet, communication platforms emerged in social media. IMWs use social media to interact and self-actualize by sharing pictures, thoughts, and videos. Starting from the development of communication among IMWs, we raise the following problems: 1) to what extent do IMWs use social media as a medium for social activism, especially for IMW protection issues? 2) What is the main content of social media uploaded by IMWs? To answer these questions, we use a social media activism framework within the social media platform. Social media helps the emergence of a participatory culture in a niche and individual group by transforming monologues into social dialogue so that these particular and individual groups'voices can be articulated to the broader community (Botha \& Mills 2012, Jackson \& Welles 2015, Russell et al. 2008).

The existence of social media helps people to connect with the outside world and has many positive uses. Tajudeen et al. (2018) mentioned that social media allows open communication, helping many people meet their needs. Previous studies have stated that social media can be used as the goal of a social group or organization (Go \& You 2016, Parveen et al. 2015, Treem \& Leonardi 2013). In the previous study, Anggaunitakiranantika (2017) stated that a network of friends connects IMWs on Facebook 
to strengthen brotherhood and become substantial social capital. IMWs join Facebook groups to connect with fellow immigrants from Indonesia. They feel they have relatives when they join the migrant workers' social media group. Syakriah (2017) found that IMWs use Facebook social media to spread social issues regarding migrant workers' rights and communication for social movements.

Meanwhile, the protection of migrant workers is a social issue that continues to be driven by activists. Astuti (2008) states that various countries in the world do not have precise regulations regarding the protection of migrant workers. Therefore, IMWs partly carry out social movements to insist on being given proper rights and safety. Previous studies have stated that the lack of protection for migrant workers can lead to them being exploited for hazardous work (Aini 2019, Rupita 2020, Sutaat 2008). Pudjiono \& Nugroho (2014) found that migrant workers are vulnerable to exploitation because they do not complete legal document requirements. Generally, these workers are illegal workers who are caught in human trafficking. Previous studies have stated that the protection of migrant workers is not optimal, so that migrant workers are vulnerable to exploitation (Astuti 2008, Nuraini \& Rochminarni 2013, Pudjiono \& Nugroho 2012). This study aims to analyze to what extent social media is used by IMWs for social activism related to issues concerning the protection of migrant workers and what influences their behavior when using social media.

\section{Research Methods}

Data were collected through participant observation, in-depth interviews, and focus group discussion (hereafter called FGD) from March until September 2019. Group interviews are useful for conducting evaluations where participants can express multiple perspectives of the same experience (Glesne 2011). FGD provides more benefits to research because individuals in groups or communities will express their opinions and experiences more than when asked to write their opinions (Harrell \& Bradley 2009). We choose the qualitative method because we want to get the media narrative on social activism. We conducted FGDs on IMWs problems during pre-departure, departure, and after returning home, and we conduct field research in Malang. East Java Province is the largest sending IMWs province, and Malang is the largest Regency sending IMWs. Other areas in the sequence are Ponorogo, Trenggalek, Blitar, Jember, Tulungagung, and Madura Regencies.

FGDs held twice, and the first FGD invited 15 representatives from the East Java Community and Development Assessment Institute or Lembaga Pengkajian Kemasyarakatan dan Pembangunan (LPKP), Gender Research Center of Brawijaya University Malang, Office of Women Empowerment and Child Protection in Malang, Indonesian Migrant Workers Union or Serikat Buruh Migran Indonesia (SBMI) Malang. The second FGD invited 25 IMWs with placement experience in Hong Kong, Taiwan, Malaysia, and Saudi Arabia. Focused discussions were held in small groups accompanied by researchers, and the first FGD divide into three small groups. The small group discussions were presented and discussed in a panel session attended by all FGD participants. The FGD was divided into five small groups, and the small group discussion results were presented and discussed in a panel session attended by all participants. The data obtained in the FGD used to find out the arguments and confirmation of secondary data found in the news, reports, and previous research.

\section{Results and Discussion}

\section{IMWs as a vulnerable group for human trafficking}

Women in developing countries migrate for employment reasons. They migrate without being accompanied by their family, husband, or children due to limited employment opportunities, poverty, and other challenging conditions in their home country (Sijapati 2015). According to Badan Nasional Penempatan dan Perlindungan Tenaga Kerja Indonesia (2019), the number of IMWs until June 2019 was 70.258 people, higher than in 2017, only 63.762 people, and in 2018 it was 67.708 people. The number of IMWs women still dominates, the number more than doubled. Data for 2018 show that the number of female IMWs is 47.708 people, while male IMWs is 20.035 (Badan Nasional Penempatan dan Perlindungan Tenaga Kerja Indonesia 2019). 
Jobs as domestic servants (29.42\%) and caregivers (21\%) still dominate IMWs job placements. The rest are operators, agricultural laborers, technicians, heavy equipment operators, construction workers, and cleaners (Badan Nasional Penempatan dan Perlindungan Tenaga Kerja Indonesia 2019). The demand to work in the domestic sector increases because countries with several workers who have higher skills and education have difficulty finding local workers willing to do low-paying domestic jobs and long working hours. Higher wages than in countries of origin and high demand make working abroad attractive even though these jobs are prone to exploitation (Amnesty International 2013). The distribution of IMWs jobs in vulnerable and low-paid sectors is because of their elementary school' education. Data for 2017 show that around 8.747 IMWs have educational backgrounds of elementary school graduates, 6.732 junior high school graduates, and 5.632 high school graduates. The number of IMWs undergraduate graduates is minimal, only 201 people in 2017 and 163 people in 2018 (Badan Nasional Penempatan dan Perlindungan Tenaga Kerja Indonesia 2019). The lure of changing social and economic conditions when somebody became an IMWs was the primary motivation. One of the informants, SH, a former IMW in Malaysia and Saudi Arabia, said:

"When this rural village is lured by plane, having a foreign boyfriend and returning home rich will be the main motivation for them to leave, especially those who are not married."

IMWs recruitment is joint in minus areas. Jobs in the villages are available, however not sufficient, the only way is to work abroad. Moreover, if an IMW appears successful in one village, the other villagers will be easier to recruit. According to one informant, AS, counselor, and a former IMW in Hong Kong and Malaysia, said:

"There are jobs in the villages; however, the wages are low, so they have to find other jobs. Especially in dry areas where the wages are not much. Especially if they see that the houses are big, so they want to work outside to become IMW."

According to the informants UH \& SH, a counselor and former IMWs in Saudi Arabia, they added that another factor is religious motivation. They can perform the pilgrimage in Saudi Arabia, although the number of violence against Indonesian migrant workers is also significant.

Low educational background, language limitations, and limited skills have resulted in IMWs working in many vulnerable sectors, such as domestic helpers, carers, and laborers. These jobs have long working hours and are often subject to violence. One of the informants, a former IMW who worked in Taiwan, said that he had to work 12 hours a day, standing up and even eating while standing up when he worked as a laborer. For workers who work as domestic helpers, they have to sleep and live in the employer's house. Those examples indicate the imbalance of power relations between workers and employers, and women have to work long hours and live in isolation. Constable (1997) states that isolation makes them vulnerable to verbal, sexual, and physical abuse.

This situation is getting worse, considering women still dominate the numbers of IMWs. Komisi Nasional Anti Kekerasan terhadap Perempuan (2019) notes that women experience multiple violence layers at the individual and system levels. Self-defense, domestic violence victims at home, inhuman working conditions, entrapment of trafficking syndicates, and illegal drugs are individual situations and systems that make violence against women even more layered. Furthermore, Komisi Nasional Anti Kekerasan terhadap Perempuan (2019) found that IMWs women often experience violence, the types, and patterns that have never changed in twenty years. IMWs women experience physical and sexual violence, are restricted from accessing information, experience document manipulation, confiscated documents, inappropriate work contracts, excessive working hours and workload, are prohibited from returning to their homeland, are prohibited from worshiping, and are trapped in debt and extortion (Komisi Nasional Anti Kekerasan terhadap Perempuan 2019).

Ministry of foreign affairs data shows 28.330 complaints in 2018; meanwhile, 21.126 cases were handled (Kementerian Luar Negeri Republik Indonesia 2019). The cases handled related to IMWs 
were: 1) 62 Indonesian citizens under the death penalty, two people being executed with 166 remaining cases still being handled, 2) refund of remaining salaries, insurance, and fines up to 129.630.880.939 IDR, 3) the criminal act of trafficking in persons totaling 88 cases, and 4) facilitation of the return of thousands of IMWs facing vulnerable situations abroad (Kementerian Luar Negeri Republik Indonesia 2019). Badan Nasional Penempatan dan Perlindungan Tenaga Kerja Indonesia (2019) data show that the number of IMWs complaints at the Crisis Center has also increased every year. In 2017, the number of complaints was 228 cases, while in 2019 (until June), it was 1.903 cases. Malaysia and Saudi Arabia are the most frequently requested placement countries. April-June 2019 data show Malaysia is the country with the highest number of complaints, as much 1.200 and Saudi Arabia in the second, with 256 complaints. The numbers are impressive because of the country with the most IMWs destinations in Taiwan, with 20.520 people, Malaysia is number two with 20.367 people, while Saudi Arabia is number six with 1.660 IMWs (Badan Nasional Penempatan dan Perlindungan Tenaga Kerja Indonesia 2019).

Traffickers are usually neatly organized across regions, provinces, and even countries. They often involve recruitment agencies such as PJTKIs, document-producing officials, brothel owners and leaders, relatives of victims, and even husbands or parents. The government has made efforts to prevent human trafficking by issuing 1) Presidential Instruction Number 6 of 2006 concerning the Policy on Reform of the Placement and Protection of Indonesian Workers, 2) Presidential Decree Number 81 of 2006 concerning the National Agency for the Placement and Protection of Indonesian Workers, 3) Law Number 39 of 2004 concerning the placement and protection of Indonesian Workers abroad, 4) Law Number 21 of 2007, and 5) the latest Law Number 18 of 2017 concerning the Protection of Indonesian Migrant Workers will sanction a revocation permit for PJTKI when involved in trafficking in persons. Likewise, the supreme court has expanded the court's powers by allowing companies involved in trafficking in persons to be tried. In reality, this law is not sufficient (Kansil 2009).

IMWs are prone to experiencing violence following the recruitment process, and field officers carry out recruitment in villages. PJTKIs only exist in big cities, field officers not tied to specific PJTKIs, and they are more like a broker. According to the FGDs participant from SBMI, SY, the field officer equipped with an official decree from a PJTKIs; however, the one who became a field worker could not match the name in the decree or the name in the same decree; thus, the agents represented were not the same. This practice is expected, depending on the agency's level of wages PJTKIs; therefore, tracking the perpetrators becomes difficult. Based on the FGDs participants' information from the accompanying element, the field officer wage for one IMWs dispatched varied; a maximum of eight million IDR for the destination country of Singapore, Hong Kong, or Taiwan. The amount of this incentive allows field officers to be anyone, such as the village head, teachers, neighbors, and families. Based on the informants' SI, SH, \& SY, the field officer is considered one of the triggers for rampant trafficking in the villages.

The FGDs found that IMWs' violent background was the trigger and the recurrence of violence. IMWs consider that working abroad is an effort to get out of domestic violence, the demands of living expenses, and elevate family status. This situation makes IMWs increasingly trapped by the field officer's offer that they can leave quickly. As a result, many IMWs departed illegally and were not traced. One of the informants said that most violence problems against IMWs are in the country of origin from a companion Non-Governmental Organization (NGO). Problems include inadequate skills, limited language skills, low education, underage, and falsification of documents. The informant added that departure procedures take a long time, including preparing job skills, language skills, and document preparation.

The FGDs also received information on destination countries' problems, ranging from the limited local laws governing the protection of blue-collar migrant workers, the absence of agreements between countries for sending IMWs, to the limited funds of Indonesian representatives abroad for handling IMWs problems and the IMWs factor also affects matters. IMWs mutually cover up acts of violence that occur for fear of impacting work contracts and a culture of shame when talking about being unsuccessful. 


\section{Social media as IMWs' communication channel}

It was explained at the outset that most IMWs experienced isolation because of the type of work. Working in the domestic sector, for example, makes them limited in being able to socialize with fellow IMWs because they live at the employer's house and have long working hours. IMWs were using the internet to interact with their friends and family. Thompson (2009) found that smartphones play a role in providing job information and social gatherings among migrant workers. The internet considers appropriate because it has a unifying character, low cost, broad reach, and low censorship limitations (Lim 2003). Lim \& Kann (2008) add that the internet has a better range of freedom, independence, creativity, and collaboration than other media.

Everyone in the city or village is increasingly connected to this new media and even feels a high dependence, especially on social media. Asosiasi Penyelenggara Jasa Internet Indonesia (2016) survey shows that Indonesia's internet penetration has doubled in just four years between 2012 and 2016, from 63 million to 132.7 million users. The internet is a form of computer interconnection worldwide that connects individuals in a global computer network and experiences virtual reality. In this virtual world, individuals offer different versions of events, given us a new medium different from traditional media. The internet has the main characteristics of an interactive medium. Through this interactivity, internet users have the opportunity to determine what information they want and need.

Social media is a popular internet feature and facilitates the emergence of more original content, distributes processes and interactions, and unifies media formats. Social media is a space that manifests participatory democracy, especially when it creates horizontal connections between individuals. Networking does not only refer to the existence of a system; however, it has become an incarnation of ideal conditions or guidelines that rationally provide a model for the emergence of a new format of social, cultural, even political movements affiliated not only on a local but also national and global scale. Data from the Ministry of Communication and Information or Kementerian Komunikasi dan Informatika show that social media is the most popular activity carried out by Indonesian teenagers online. Social media is an activity that is even more popular than just browsing information. The same study was disclosed by Asosiasi Penyelenggara Jasa Internet Indonesia (2014), reporting that $87.4 \%$ of Indonesian netizens use their internet access for social media.

The emergence of social media has contributed to the emergence of a participatory culture characterized as an amateur, non-market-based, corporate network to produce and share cultures, niches, and special groups (Russell et al. 2008). Social media transforms monologues into social dialogue (Botha \& Mills 2012). Social media makes marginal voices heard and articulated to the masses (Jackson \& Welles 2015). Social media accommodates social relationships and networks. The existing network on social media reflects the offline situation. Individuals are grouped based on age, interests, and certain social and cultural similarities. Most Indonesians under 25 do not use the same network as older citizens. They are differentiated based on groups, interests, issues, and conversations (Lim 2003).

Social media such as Facebook offer transparency and, at the same time, obscure the issue considering that there are so many connected networks, as previously explained. Consumption of information via Facebook is also not voluntary. When compared to its predecessor, namely blogs, there is an interaction between bloggers and their readers. Readers read and comment voluntarily. On Facebook, reading activities (at a glance) is not always voluntary. When information is given through the newsfeed, there is the possibility of reading and listening to each other, allowing mutual communication between strangers. If the previous internet allowed the individual to be anonymous and unconfirmed, then on Facebook, the individual can be seen and confirmed so that peers' and enthusiasts' pressure can be higher. The significant confirmation on Facebook resulted in Facebook users observing each other (Egebark \& Ekström 2011).

Facebook also makes it possible to turn writing and content creation into joining and sharing. Sharing activities can be carried out without prior involvement in content production, just by pressing the 'share' 
button. Facebook also makes it possible to expand conversations from one-on-one conversations to a combination of one-on-one, one-many, or many-many conversations that run simultaneously in public. Therefore, friendship on Facebook has a weak bond; these weak ties can, in turn, lead to the formation of phenomena at the macro level, such as online mobilization. Weak networks allow group members to join different small groups that concentrate on forming a particular group. Weak ties at the individual level can open and expose interpersonal networks to external influences on specific individuals in distant networks, which helps this information be enjoyed by a more extensive mass (Goldenberg et al. 2001). Lovejoy \& Saxton (2012) state that social media facilitates access to many contacts, driving social movements to reach mass criticism. Social media promotes the construction of personal and group identities (Dalton et al. 2010) by providing various channels for criticism, acceptance by groups, and recognition of group norms (Papacharissi 2010). Bimber et al. (2005) define it as a set of communication processes that involve crossings between private and public life. Social media users form opinions according to the needs of the groups they follow (Gil de Zúñiga et al. 2014) and form group attitudes, views, and behaviors (Haciyakupoglu \& Zhang 2015).

Therefore, communication between IMWs can be used for positive change in the recruitment process, placement, and changes in work situations. Hug (2012) states that these actions are referred to as media activism, a form of participation in the media to create social changes from these activities. Social media restores the role of narrative as an essential medium for understanding and organizing experiences. A narrative is a conventional form of transmitting experience and understanding culturally as a form of a version of reality, which can then be called a discourse or mode of thought. This narrative will effectively communicate information and IMWs' experiences when working abroad so that it expects to create attachments of interests, goals, and feelings so that messages are easier to understand.

The FGDs found several narratives from IMWs on their social media. First, IMWs' social media contain more of the festive activities they do, such as shopping, eating out, and traveling. All of this shows the success of IMWs. Second, IMWs inform more about general matters which do not concern employers and agents. They do this because there is a fear of threatening the continuation of the contract. Daily, things they usually talk about are tips on avoiding brokers, tips on saving salary, and tips for avoiding fraud. Third, IMWs mostly provide news information packaged in a relaxed and humorous manner, such as breakups, messages to children, and families.

We found that this lively narrative is primarily influenced by the cultures of the countries of origin and destination countries. IMWs are placed in a country with a more open culture, where local laws are more transparent in protecting IMWs, so the content of IMWs' social media is more open and willing to provide testimony on the problems that exist around them. An example of such a country is Hong Kong. Meanwhile, when IMWs place in a country that tends to be closed, and there is almost no local law on IMW protection, such as Malaysia and Saudi Arabia, IMWs tend to be closed in expressing themselves through social media. The culture of the country of origin is also influential. We found four influences. First, in Indonesia, reporting failure is taboo. One of the informants, and IMW's companion, said there is a culture of shame in delivering testimony of failing. Second, IMWs are afraid of getting intimidated by agents and families if they tell about failures. Third, IMWs coverup stories of failures and problems faced because they are still under contract, so they become very dependent and do not want to speak out. Fourth, IMWs do not tell the problems they are facing on purpose to make more friends who feel the same way.

We also found communication strategies that can be packaged at a later date. First, it is better if the packaging of content in social media, such as video blogs, is done by a third party, summarized from several closed interviews. The content is usually a semi-documentary. Second, in extracting information from IMWs, it is better to explore general issues and leave the IMW to tell the story without trying to conclude. It is to gain the IMW's trust. Third, to start creating content from IMWs, there needs to be an example that has gone viral. Whether it is viral or not, IMWs are motivated to create content for protection. Fourth, former IMWs are more open and able to bring up stories of their experiences because there is no burden to return to being an IMW. 


\section{Conclusion}

Communication in both home and destination countries influences how social media content produced by IMWs influences protection efforts. The second factor that affects is the clarity of law related to IMWs in the destination country. Therefore, although social media is massive among IMWs, it is not linear with content production that leads to protection.

Many netizens use social media as a medium for activism. Social media with networked characteristics has succeeded in bringing up narratives in a niche and special groups that have not been heard a lot and have escaped mainstream media scrutiny. By conducting research on NGOs engaged in IMW issues, IMW assistants, former IMWs, and IMWs in Malang Regency, we found that most IMWs used social media to communicate between themselves and their families in the country. However, social media content for social activism is low, especially for the issue of IMW protection. The culture and legal systems in the countries of origin and destination countries affect the low level of participation in the content they create. If IMWs are placed in a country with a more open culture, where local laws are more precise in protecting IMWs, then the content of IMWs' social media is more open and willing to provide testimony on their problems and vice versa.

The home country's culture still considers the news of failure taboo and, therefore, tends to cover it up. Moreover, there are many backgrounds to become an IMW because of previous violence, so that a success story is a form of catharsis over previous violence that occurred in the country of origin, such as domestic violence, running from debt, and poverty. Therefore, IMWs prefer to include festive activities, such as shopping, eating out, and traveling. IMWs also mostly provide news information packaged in a relaxed and humorous manner, such as breakups and messages to children and families. For advocacy, IMWs provide more information on general matters that do not concern employers and agents. They do this because there is a fear of threatening the continuation of the contract. They usually talk about avoiding brokers, tips on saving salary, and tips for avoiding fraud. The legal system in question includes the limited local laws governing blue-collar migrant workers' protection, the absence of agreements between countries for sending IMWs, and the limited funds of Indonesian representatives abroad to handle IMW problems.

\section{References}

Aini AN (2019) Peran Konsulat Jenderal Republik Indonesia (KJRI) di Penang dalam perlindungan tenaga kerja wanita pada masa penempatan. Thesis, Universitas Diponegoro, Semarang.

Amnesty International (2013) China: Exploited for profit, failed by governments: Indonesian Migrant Domestic Workers trafficked to Hong Kong. [Accessed 20 December 2019]. https://www. amnesty.org/en/documents/ASA17/029/2013/en/.

Anggaunitakiranantika A (2017) Interaksi buruh migran perempuan sebagai kekuatan modal sosial. Jurnal Sosiologi Pendidikan Humanis 2 (1):33-40. https://doi.org/10.17977/um021v2 i12017p033.

Asosiasi Penyelenggara Jasa Internet Indonesia (2014) Profil pengguna internet Indonesia. [Accessed 20 December 2019]. https://apjii.or.id/survei2014/download/XldaA4mS87ThVUBQ0FIoN Cgn6MRLEK.

Asosiasi Penyelenggara Jasa Internet Indonesia (2016) Penetrasi dan perilaku pengguna Internet Indonesia. [Accessed 20 December 2019]. https://apjii.or.id/downfile/file/surveipenetrasi internet2016.pdf.

Astuti B (2008) Sertifikasi uji kompetensi sebagai upaya perlindungan hukum bagi Tenaga Kerja Indonesia/Tenaga Kerja Wanita Penata Laksana Rumah Tangga (TKI/TKWPLRT). Thesis, Universitas Diponegoro, Semarang.

Astuti TMP (2008) Antropologis tentang trafficking TKW di Malaysia: Antara ada dan tiada. Forum Ilmu Sosial 35 (2):113-123. 
Badan Nasional Penempatan dan Perlindungan Tenaga Kerja Indonesia (2016) Renstra BNP2TKI Tahun 2015-2019. [Accessed 20 December 2019]. http://portal.bnp2tki.go.id/read/11424/ RENSTRA-BNP2TKI-TAHUN-2015-2019.html.

Badan Nasional Penempatan dan Perlindungan Tenaga Kerja Indonesia (2019) Data penempatan dan perlindungan PMI periode Juni 2019. [Accessed 20 December 2019]. http://www.bnp2tki. go.id/uploads/statistik/images/data_12-07-2019_Laporan_Pengolahan_Data_BNP2TKI Bulan_JUNI_1_REV.pdf.

Bimber B, Flanagin AJ, \& Stohl C (2005) Reconceptualizing collective action in the contemporary media environment. Communication Theory 15 (4):365-388. https://doi.org/10.1111/j.14682885.2005.tb00340.x.

Botha E \& Mills AJ (2012) Managing New Media: Tools for Brand Management in Social Media. In: Angeline GC (ed). Online Consumer Behavior: Theory and Research in Social Media, Advertising and E-Tail. New York: Taylor \& Francis.

Constable N (1997) Maid to Order in Hongkong: Stories of Filipina Workers. New York: Cornell University Press.

Dalton R, SickleAV, \& Weldon S (2010) The individual-institutional nexus of protest behaviour. British Journal of Political Science 40 (1):51-73. https://doi.org/10.1017/S000712340999038X.

Egebark J \& Ekström M(2011) Like what you like or like what others like? Conformity and peer Effects on Facebook. In: IFN Working Paper No 886, Stockholm: Research Institute of Industrial Economics. [Accessed 20 December 2019]. https://www.econstor.eu/bitstream/10419/ 81323/1/wp886.pdf.

Gil de Zúñiga H, Molyneux L, \& Zheng P (2014) Social media, political expression, and political participation: Panel analysis of lagged and concurrent relationships. Journal of Communication 64 (4):612-634. https://doi.org/10.1111/jcom. 12103.

Glesne C (2011) Becoming Qualitative Researchers: An Introduction (4 ${ }^{\text {th }}$ ed). Boston: Pearson.

Go E \& You KH (2016) But not all social media are the same: Analyzing organizations' social media usage patterns. Telematics and Informatics 33 (1):176-186. https://doi.org/10.1016/j. tele.2015.06.016.

Goldenberg J, Libai B, \& Muller E (2001) Talk of the network: A complex systems look at the underlying process of word-of-mouth. Marketing Letters 12 (3):211-223. https://doi.org/ 10.1023/A:1011122126881.

Haciyakupoglu G \& Zhang W (2015) Social media trust during the Gezi Protests in Turkey. Journal of Computer Mediated Communication 20 (4):450-466. https://doi.org/10.1111/jcc4.12121.

Harlow S \& Guo L (2014) Will the revolution be tweeted or facebooked? Using digital communication tools in immigrant activism. Journal of Computer-Mediated Communication 19 (3):463-478. https://doi.org/10.1111/jcc4.12062.

Harrell MC \& Bradley MA (2009) Data Collection Methods: Semi-Structured Interview and Focus Groups. Santa Monica: RAND National Defense Research Institute.

Hug $\mathrm{T}$ (2012) Explorations in the tension between media activism and action-oriented media pedagogy. Journalism and Mass Communication 2 (3):457-463.

Jackson SJ \& Welles BF (2015) Hijacking \#MYNYPD: Social media dissent and networked counterpublics. Journal of Communication 65 (6):932-952. https://doi.org/10.1111/ jcom. 12185 .

Kansil CST (2009) Tindak Pidana dalam Undang-Undang Nasional. Jakarta: Jala Permata Aksara.

Kementerian LuarNegeri Republik Indonesia (2019)Laporankinerja tahun 2018. [Accessed 10 January 2020]. https://kemlu.go.id/download/L3NpdGVzL3B1c2F0L0RvY3VtZW50cy9MS0pfS2 VtZW5sdV8yMDE4LnBkZg==.

Komisi Nasional Anti Kekerasan terhadap Perempuan (2019) Laporan independen lembaga nasional Hak Asasi Manusia tentang 25 tahun pelaksanaan kesepakatan Global Beijing Platform for Action (BPfA+25) di Indonesia. Disampaikan kepada Commission on the Status of Women (CSW), 27 September 2019. [Accessed 10 January 2020]. https://komnasperempuan.go.id/ laporan-internasional. 
Lim M (2003) The Internet, Social Network, and Reform in Indonesia. In: Nick CJC (ed). Contesting Media Power: Alternative Media in a Networked World (Critical Media Studies: Institutions, Politics, and Culture). Lanham: Rowan and Littlefield.

Lim M \& Kann M (2008) Politics: Deliberation, Mobilization, and Networked Practices of Agitation. In: Varnelis K (ed). Networked Publics. Cambridge: MIT Press.

Lovejoy K \& Saxton GD (2012) Information, community, and action: How nonprofit organizations use social media. Journal of Computer-Mediated Communication 17 (3):337-353. https:// doi.org/10.1111/j.1083-6101.2012.01576.x.

Nuraini I \& Rochminarni AB (2013) Potensi sumber daya daerah dan kesejahteraan keluarga TKI. Jurnal Ekonomi Pembangunan 11 (2):1-17. https://doi.org/10.22219/jep.v11i2.3741.

Papacharissi Z (2010) A Networked Self: Identity, Community, and Culture on Social Network Sites. New York: Routledge.

Parveen F, Jaafar NI, \& Ainin S (2015) Social media usage and organizational performance: Reflections of Malaysian social media managers. Telematics and Informatics 32 (1):67-78. https://doi.org/10.1016/j.tele.2014.03.001.

Pudjiono MJ \& Nugroho SS (2014) Pertanggung jawaban pidana pelaku tindak pidana perdagangan orang (Trafficking). Jurnal Sosial 15 (1):43-53.

Rupita (2020) Kehidupan perempuan perbatasan: Kemiskinan dan eksploitasi (Kajian kasus di perbatasan Jagoi Indonesia-Malaysia Kalimantan Barat). Ganaya: Jurnal Ilmu Sosial dan Humaniora 3 (1):135-145. https://doi.org/10.37329/ganaya.v3i1.429.

Russell A, Ito M, Richmond T, \& Tuters M (2008) Culture: Media Convergence and Networked Participation. In: Kazys V (ed). Networked Publics. Cambridge: MIT Press.

Sijapati B (2015) Women's labour migration from Asia and the Pacific: Opportunities and Challenges. [Accessed 20 December 2019]. https://www.migrationpolicy.org/research/womens-labourmigration-asia-and-pacific-opportunities-and-challenges.

Sutaat S (2008) Masalah sosial Tenaga Kerja Wanita Indonesia di shelter KBRI Kuala Lumpur. Sosio Konsepsia 13 (2):1-14.

Syakriah A (2017) Aktivisme Buruh Migran Indonesia (BMI) melalui media sosial (Studi kasus pada aktivisme BMI melalui Facebook). Thesis, Universitas Airlangga, Surabaya.

Tajudeen FP, Jaafar NI, \& Ainin S (2018) Understanding the impact of social media usage among organizations. Information \& Management 55 (3):308-321. https://doi.org/10.1016/j.im. 2017.08.004.

Thompson EC (2009) Mobile phones, communities and social networks among foreign workers in Singapore. Global Networks 9 (3):359-380. https://doi.org/10.1111/j.1471-0374. 2009.00258.x.

Treem JW \& Leonardi PM (2013) Social media use in organizations: Exploring the affordances of visibility, editability, persistence, and association. Annals of the International Communication Association 36 (1):143-189. https://doi.org/10.1080/23808985.2013.11679130. 